\title{
Las emociones en el aprendizaje de una lengua extranjera: su impacto en la motivación
}

\author{
Mariza G. Méndez López \\ Universidad de Quintana Roo \\ marizam@uqroo.edu.mx
}

Resumen: Este artículo presenta una revisión de investigaciones afectivas para identificar el rango de emociones experimentadas por estudiantes de una lengua extranjera en diferentes contextos, las situaciones que han originado esas emociones y como éstas han afectado su motivación. En la presente revisión, la influencia dominante de las emociones en la motivación de estudiantes de una lengua extranjera es demostrada. Las causas que influyen más en las experiencias emocionales reportadas en los diferentes estudios analizados son: profesores, compañeros, habilidad oral, enfoque de retroalimentación y el ambiente de aprendizaje. Esta revisión intenta crear conciencia sobre el papel determinante de las emociones en la motivación en el aprendizaje de una lengua extranjera, enfatiza las implicaciones de la investigación en emociones para profesores de lenguas extranjeras y sugiere direcciones para investigaciones futuras.

Palabras clave: emociones; motivación; aprendizaje de lenguas extranjeras.

Abstract: This article presents a review of affective research to identify the range of emotions experienced by learners across different settings, the situations that have created these emotions and how these have affected their motivation. In the current review the pervasive influence of emotions on the motivation of foreign language learners is revealed. The most influential causes of emotional experiences reported in the different studies analysed are: teachers, peers, speaking skills, teachers' feedback approaches and the learning environment. This review helps to raise awareness about the determinant role of emotions in language learning motivation, highlights the implications of research on emotions for language teachers and suggests directions for future research.

Keywords: emotions; motivation; foreign language learning. 


\section{Introduction}

Affective aspects are core elements in motivation and success in foreign language learning and teaching (Arnold and Brown, 1999). Their crucial importance has been emphasised since the seminal studies on second language learning motivation (Gardner and Lambert, 1959) and theories of language learning (Krashen, 1985). Despite their importance, emotions have been eclipsed in motivation research because of the interest in cognition (MacIntyre, MacKinnon and Clément, 2009). Besides, affective research in language learning has privileged constructs such as anxiety, self-esteem and beliefs. Although studies on these topics have advanced our knowledge, other affective factors have not yet been given enough attention in language learning research (Dewaele, 2011; Benesch, 2012; Swain, 2013) and studies involving emotions in foreign language learning are scarce (Mercer, 2005; Garret and Young, 2009, Imai, 2010, Méndez and Fabela, 2014; Méndez, Marín and Hernández, 2015).

In this article, I present a review of research studies to identify the range of emotions experienced by learners across settings, the situations that originate these emotions and how these have affected their motivation. In this review, the pervasive influence of emotions in foreign language learners' motivation is revealed. The most influential causes of emotional experiences reported in the different studies reviewed are teachers, peers, the speaking skill, teachers' feedback approaches and the learning environment. Emotions, whether negative or positive, have both a negative and positive influence (Linnebrick-Garcia and Pekrun, 2011; Benesch, 2012; Méndez and Fabela, 2014). Although no clear conclusions have been established regarding the shaping effects of intensity and frequency of emotions in learning (Hascher, 2007), negative and positive emotions have been found to enhance not only learning processes but also the development of learners (Imai, 2010; Méndez and Fabela, 2014). Understanding the emotional processes that underlie foreign language learning is important since they can enable us to comprehend students' reactions to instruction, and may provide us with insights on how to make it a more effective process. Thus, their significance needs to be emphasised since emotions are involved in all stages of a language learning process and play a crucial role in learners' motivation and success.

\section{Emotions and their connection to motivation}

Cognition has been highlighted in ELT research in spite of the interplay that affect has on learning (Arnold, 1999; Mercer, 2005; Swain, 2013). However, there 
are numerous scholars who have acknowledged that foreign language learning is emotionally driven (MacIntyre, 2002; Méndez, 2011). Fear and anger have been found to risk foreign language learners' motivation (Benesch, 2012), thus it is important to pay attention to language learners' emotions in order to help them overcome demotivation. Promoting positive emotions in classrooms can enhance self-esteem and promote empathy among peers. In addition, teacher and peer support can contribute to reenergising motivation and facilitating language learning among students (Zarrinabadi, 2014; Méndez, Marín and Hernández, 2015).

Emotions, feelings and moods are all integral components of affect. The first two terms are included interchangeably in education literature (Scherer, 2005) and are considered to have many similarities (Efklides and Volet, 2005); Ekman (2003) acknowledges that emotions and moods involve feelings, meaning that feelings are a component of both, which may be why there no definite separation has been made. Along the same lines, Prinz (2005) states that emotions are feelings and both terms refer to perceptions of bodily changes: when these perceptions are conscious they are feelings, whereas when they are not conscious they are emotions. However, the role of bodily feelings in the experience of an emotion remains an open question since there are no conclusions from the extense research in this area (Barret, Mesquita, Ochsner, and Gross, 2007).

Emotions are said to be context-dependent, short-lived and subjective responses to a specific situation, object or person (Do and Schallert, 2004; Sansone and Thoman, 2005; Hascher, 2008) and certain mental processes (Schumann, 1998), so the combination of emotional experiences with the diverse external factors learners are exposed to in any learning situation strongly influences learning outcomes. Although emotions can be labelled as either positive or negative. Emotions per se are not detrimental or beneficial for learning processes (Imai, 2010; Benesch, 2012); they are individually experienced and a single situation can evoke different emotional reactions. Thus, the convergence of individual differences, emotional events and the socio-cultural factors of the context in which learning takes place determines the relevance of emotions to learners' motivational behaviour. The consequent interplay will result in markedly different emotional reactions among learners that will modify their motivational energy. Therefore, the motivational energy foreign language learners display in classrooms is continuously regulated by their emotions, and the outcomes of positive and negative emotions can be either beneficial or detrimental for their learning processes. 
Emotions are embedded in the particular situation that causes them. In language classrooms, they might result from interactions with the teacher, peers or specific learning materials, or a students' own feelings could initiate an emotional response (Sansone and Thoman, 2005; Scherer, 2005; Hascher, 2008). Emotions can also result in particular motivational behaviours from students: to continue trying to solve a particular learning task, or to stop trying because of a negative emotion (Scherer, 2005). The intensity of the feelings being experienced, and this intensity variation might explain individual appraisals and students' subsequent actions (Scherer, 2005; Hascher, 2007, 2008). Barret et al. (2007: 376) state that "... an adequate account of emotion experience requires more than a specification of cause; it also requires a description of content (i.e., of what is felt)...". Although no clear conclusions have been reached regarding the shaping effects of emotional intensity and frequency in learning (Hascher, 2007), negative and positive emotions have been found to enhance not only learning processes but also learners' development (Imai, 2010).

Emotions are elicited because of the individual value given to a particular situation, person or object. As such, emotional situations may provoke different reactions in students according to the importance they give to each particular situation, object or person's influence on the achievement of their particular goals (Do and Schallert, 2004; Scherer, 2005). Emotional experiences in language learning classrooms consequently engender reactionary feelings, physiological responses and observable behaviour. In this way, emotions influence the motivation language learners exhibit during learning activities.

\subsection{Emotions experienced by foreign language learners}

Language learning classrooms stimulate diverse emotional experiences in students that have a powerful effect on student interest and motivation (Méndez, 2011). Emotions experienced by students are considered important in understanding learning processes, student motivation and effective teaching (Cowie, 2011; Benesch, 2012; Swain, 2013).

Emotions are a result of the evaluations students make of particular situations while learning (Pekrun, 2000). These evaluations are influenced by previous experiences, the social context and their personal goals (Pekrun et al., 2002; Sansone and Thoman, 2005). The interplay of all these variables in one emotional event during classroom instruction may have different meanings for individual students and cause diverse motivation impacts (Méndez and Fabela, 2014). The resulting tasks learners decide to carry out account for the amount of motivational variation language learners go through during the different stages 
of their learning processes (Shoaib and Dörnyei, 2004). These temporal and multiphase aspects of motivation have been separated into three stages: reasons for doing something, deciding to do something, and sustaining the effort or persisting (Williams and Burden, 1997:121). In these three phases, emotional experiences play a significant role as they are a fundamental aspect of the decision to study a foreign language or keep up with the task. Those emotions experienced during foreign language learning instruction are then important in understanding how language teachers can adjust their approaches in order to reduce the negative impact emotions can have on learners' motivation and also enhance the promotion of those emotions that can activate it.

\subsection{Factors influencing emotions experienced in language learning}

Without doubt, all who have experienced learning a foreign language would agree on the influence of the context, teachers, learning experiences and external sources such as peers or significant others in the process. In the following section, the findings on emotions studies conducted in different contexts will be detailed along with an explanation of how the emotions generated by diverse learning experiences affected language learners.

Mercer (2005) asked 73 Austrian university students to keep a weekly diary to report their experiences while learning English as an additional language. Participants in Mercer's study reported anxiety as the most frequent emotion; this was because of students' fear of making mistakes or taking an exam. In addition, teacher feedback provided after a class activity or test was considered demotivating for some students and motivating for others. Mercer pointed out that it is not possible to study the complex reality of language learners by only considering their language classroom experiences and advised considering the learner for a complete understanding of motivation.

Garret and Young (2009) explored the emotional reactions occurring during a Portuguese classroom course for a period of eight weeks. Although their study was not focused on accounting for emotions, emotions became the core of the description in Garret's responses to instruction, highlighting the significant role emotions play in language learning processes. Garret and Young (2009) described 255 positive emotional experiences and 69 negative ones. Positive and negative experiences were mainly engendered because of the teacher's voice, social relations, cultural learning and language awareness. The personal experience of the emotional impact of learning a foreign language made Garret reconsider her instructional approach and adjust it in order to promote positive affiliation 
among students, emphasise cooperation in learning tasks and be sensitive about forcing beginners to speak the target language. Experiencing being a beginner in any instructional setting is a powerful developmental force for teachers.

Imai (2010) investigated the manifestation of emotions during groupwork preparation for an oral presentation to an English class. He found that during task preparation language learners' mental processes were structured through the verbalisation of their emotions, which then developed into common group feelings; thus, emotions felt by the three members of the group served to construct the same feelings towards the activity through negotiation of their reactions to the learning task in question. From this, Imai (2010) concludes that even negative emotions can be a significant developmental resource for foreign language learners.

Although conducted under a self-regulatory framework, the study carried out by Bown and White (2010) also reflects the emotional experiences learners in classrooms go through. In the individual reflections of three learners, the interaction of their previous language learning experiences, current learning events and goals played a significant role in their motivational behaviour. These reflections showed how even the scarce contact with instructors initiated by individuals in the learning process evoked sufficiently negative emotions that their motivation was profoundly affected. These students' emotions in face-toface interaction with instructors were evoked because of the instructors' body language, non-verbal expressions and feedback provided. Thus, the significant effect of instructors in the ELT field was displayed even in autonomous language learning experiences, which confirms that the development of positive interpersonal relations in language learning processes is a core aspect of instilling motivation and effective ELT.

In a qualitative study conducted in Mexico, Méndez (2011) found that fear was the emotion most frequently reported by language learners. Besides happiness, worry, calm, sadness and excitement were also highly reported. This study revealed that students reported more negative emotions than positive ones; thus, the array of emotions students endure during learning is vast. A significant outcome of Méndez's study is the discovery of the role played by negative emotions during learners' development and motivation. Although students reported more negative than positive emotions during the study period, these were not detrimental to their desire to finish the ELT programme (Méndez and Fabela, 2014). However, negative emotions reduced participation in classes due to students' fear about being laughed at by their peers or being negatively evaluated by teachers. Thus, it is important for teachers to enforce effective techniques that 
can contribute to the establishment and maintenance of positive interpersonal relations in any instructional situation.

A study conducted in Iran by Zarrinabadi (2014) focused on identifying the teacher factors that affected language learners' desire to communicate in English. Data was collected through a focused essay technique to allow the fifty participants to reveal their feelings regarding their speaking experience while interacting with teachers in classroom tasks. After analysis, the topics found to be affecting participation in class activities were: the teacher's wait time, the error correction method, support from the teacher, and the teacher's decision on the topic. According to this study, teachers who gave enough time to elaborate their responses and error correction methods made students feel insecure, uncomfortable and uneasy, while teachers showing support to students made them feel secure and confident. The researchers suggest that body language has to be positive in order to help foreign language learners reduce negative emotions that can make them withdraw from class activities and consequently be detrimental to their motivation.

A recent quantitative study also revealed the strong influence of teachers on language learners' motivation. Méndez, Marín and Hernández (2015) surveyed 167 students from an ELT programme in south Mexico. A questionnaire including 69 items about emotional experiences on feedback approach, oral ability, group cohesion, learning environment and interpersonal relations was given to students at different stages of this degree. The results revealed that students experience more emotions in the components of learning environment and interpersonal relations, highlighting the crucial role teachers play in the process of learning a foreign language. Thus, the link between the emotions originated by the teacher's social-emotional skills and the learners' motivation is a decisive one since these emotions are going to determine the amount of effort and interest students have regarding learning activities, influencing their motivation accordingly (Macintyre, Burns, and Jessome, 2011).

Drawing on the previous studies review, the most influential causes of emotional experiences are teachers, peers, speaking skills, the teacher's feedback approach and the learning environment. A brief discussion of these aspects is presented below. 


\section{Teachers influence on students emotions and motivation}

The main source of students' feelings and emotions in instructed foreign language learning is the teacher (Williams, Burden, Poulet, and Maun, 2004; Lei, 2007; Yan and Horwitz, 2008; Garret and Young, 2009; Méndez, Marín and Hernández, 2015). These results corroborate motivation studies in which teachers are said to be the determinant factor influencing students' motivation (Guilloteaux and Dörnyei, 2008). Teachers significantly influence the motivational behaviour displayed by learners in classrooms (Dewaele, 2014), thus the link between the emotions caused by teachers and learners' motivational behaviour is a decisive one as these emotions are going to determine the amount of effort and interest students have during learning tasks.

Motivation may be increased by the students' desire to please the teacher because they like or appreciate them or because they want to minimise their disapproval (Blumenfeld, 1992). Although this spark of motivation is extrinsic, it may evolve into an intrinsic one. The teacher's level of authority is another source for fluctuations in motivation: it can be supporting or controlling. If students perceive the teacher's authority as supportive their motivation can be increased, whereas if they perceive it as controlling there may be a detrimental effect on their intrinsic motivation (Deci and Ryan, 1985; Littlewood, 2000).

Lei (2007) found nine language teacher aspects (personality, vocation, knowledge, learning materials, classroom management, evaluation approach, affective expression, teaching approach and learning environment) that emotionally affect the learning process because of the synergy co-constructed by this interaction. Teachers engender emotions conducive to motivational energy when they are caring, humorous, genuine, knowledgeable, energetic, fair and diverse in their teaching approach (Tse, 2000; Lei, 2007; Yan and Horwitz, 2008; Garret and Young, 2009), whereas teachers who compare learners' proficiency, use sharp feedback, are judgmental, unauthentic and treat learners unfairly cause feelings that are not only detrimental to the learning process but to the learners' self-concepts as well:

The messages that teachers convey in their classrooms, both explicitly and implicitly, about what they consider successful learning... profoundly affect their learners' developing notions of themselves as learners as well as their progress. (Williams and Burden, 1999: 200) 


\section{Peers influence on students emotions and motivation}

Given that the process of instructed language learning is embedded in social interaction, interaction with teachers and peers causes diverse emotional responses that also have a strong influence on learners' motivational energy (Ushioda, 2003). Cooperation among peers has been found to elicit positive emotions, whereas competition causes negative emotions conducive to a decrease in the motivational energy displayed in classrooms (Dörnyei, 2001). A difference in the language ability among students in a group fosters comparisons with peers that engender anxiety, envy, fear and reticence to participate in the class (Woodrow, 2006; Zhang and Head, 2010). However, this comparison can also spark motivation since learners may feel they have to be at the same level as their classmates and therefore make their best efforts to achieve this (Yan and Horwitz, 2008; Méndez and Peña, 2013).

Peer pressure can evoke positive or negative emotions. A group with a high level of cohesion can cause positive emotions that are beneficial for motivation since students can adjust their performance in order to adhere to the group norms (Dörnyei, 2001; Chang, 2010), while classmates can be supportive of their peers' learning processes by helping one another with homework, encouraging the practice of English and acknowledging each other's effort and progress (Dewaele, 2014). These practices among peers are prone to engendering positive emotions that activate motivation. However, peers can also evoke negative emotions such as fear, anxiety and humiliation when mocking one another or minimising an individual's efforts and progress, which demotivates students and can even make them stop trying (Yan and Horwitz, 2008; Chang, 2010).

Peer support can help students to not only express their feelings and emotions during a learning process but also to co-construct meaning. Imai (2010) reported how students felt confused and angry because, when preparing an oral presentation, the teacher provided an article for them to support their argument. However, they had trouble incorporating the information from the article into the sketch they were preparing; after expressing anger and confusion and even questioning the teacher's knowledge and commitment, they started to coconstruct meaning through peer scaffolding. The emotional experience presented by Imai (2010) shows how emotions, although subjectively experienced, can also be socially constructed by interaction with peers and affect individual motivation directly. 


\section{Emotions while speaking in a foreign language}

The skill of speaking in the target language has been demonstrated to cause the most emotional reactions among language learners because of its interactive nature (Woodrow, 2006). Most students fear mispronouncing words or making grammatical mistakes when answering questions in front of the whole class, since they fear their peers mocking them or being negatively evaluated by teachers (Kitano, 2001). In two recent studies carried out in Chinese contexts, it is stated that the reticence to speak or participate in classroom activities can usually be attributed to the cultural and educational environment in which learners have developed, which is not enhanced by culture but by the controlling teaching practices imposed on students (Xie, 2010; Zhang and Head, 2010). I believe this is not only relevant to the Chinese context because in other contexts teachers may also make use of controlling practices when presenting a topic or giving feedback, which make students feel fearful and inhibited.

Students' interactions in class are modified because they see the teacher not as a facilitator but as an authority figure (Littlewood, 2000). Students who are taught in a class in which the teacher exercises controlling authority cannot generate or enhance their motivation; they may feel that they have no control over any of the components of their learning process and consequently they may experience frustration, discouragement and oppression. A way to help students have a sense of ownership and control over their learning is by involving them in identifying their needs and giving them choices in fulfilling these needs (Graves, 2005). According to Williams and Burden (1997: 73), an important determinant in language learning motivation is this sense of ownership which may also contribute to personal control and empowerment, thus increasing students' selfesteem. It is important therefore to provide space for student-initiated ideas that are predominantly not allowed or suppressed because they do not facilitate classroom teacher control (Jackson, 2002). Controlling practices in language classrooms leave no opportunities for students to develop linguistically and are detrimental to their motivation because there is no space for the development of learners' confidence, which results in avoidance of learning activities to protect their self-worth.

\section{Emotions engendered by feedback}

Teachers should reflect on their approaches to providing feedback since they are giving students an evaluation which is usually the only reference they have to their language learning progress. Feedback can be informational (helping 
the development of weaker areas) or controlling (making judgments about the language proficiency of students (Dörnyei, 1994)); the latter should be avoided since it can negatively affect the levels of motivational energy by making comparisons with external standards (e.g. native speakers' pronunciations) or group-related standards (e.g. comparisons to classmates' successes). A common practice in language classrooms is public praise, which can also send highly negative messages to students who may feel threatened by the comparisons students are prone to making. This practice of social comparison, which is widely used in institutions and classroom settings, is considered to be especially detrimental to learners' intrinsic motivation (Carole, 1992).

A teacher's body language can convey strong negative meanings and discourage students to participate or make a bigger effort in class, so care needs to be exercised when providing feedback. Even in a self-regulated framework where instances of face-to-face interaction were minimal and requested by learners, the facilitator's gestures and verbal feedback have been shown to have caused such negative emotions in one student that she withdrew from the course (Bown and White, 2010). Teachers should be careful about this aspect of language teaching because it can be highly damaging to the level of self-confidence and motivational behaviour evident in future learning situations.

\section{How can we create a motivating classroom climate for foreign language learners?}

Humanistic education emphasises that learning is easiest, most meaningful and most effective when it takes place in a non-threatening environment (Gage and Beliner, 1992). The learning environment is another powerful influence on students' emotional arousal and consequently on their motivational energy fluctuations (Meyer and Turner, 2002; Järvenova and Järvelä, 2005; Yan and Horwitz, 2008). It seems that this principle is the foundation for having motivated students in language classrooms since the lack of a positive classroom environment has been shown to be one of the main causes of negative emotions among students in foreign language learning, where the learning of a foreign language can be more affectively demanding for students:

...engaging students in learning requires consistently positive emotional experiences, which contribute to a classroom climate that forms the foundation for teacher-student relationships and interactions necessary for motivation to learn. (Meyer and Turner, 2006: 377) 
Thus, it is understandable that the teacher has been found to be the main cause of emotions in diverse studies; the teacher is the one who establishes the principles of classroom structure, selects materials, groups students and establishes a rapport among them, so it is his or her interpersonal skills that set the scene for the promotion of a good learning environment. According to Turner, Meyer, and Schweinle (2003), a positive classroom climate is fundamental to the promotion of positive emotions during instructional interactions in classroom settings. Three key aspects for the development of a non-threatening learning environment are:

+ creating a positive classroom climate

+ promoting group cohesion

+ establishing good teacher-student relationships.

\subsection{Creating a positive classroom climate}

Teachers need to develop strategies to make the learning environment a supportive one in which students feel confident and willing to participate. Establishing respectful and positive human relations is not an easy task, not only in the academic field, but in any aspect of human life. Thus, it is important for teachers to enforce effective techniques that can contribute to the establishment and maintenance of positive interpersonal relations in any instructional situation. There are different books that offer strategies teachers can use to make students feel comfortable in their classes.

\subsection{Promoting group-cohesion}

According to Dörnyei (2007), a crucial factor in developing a motivating classroom environment is :.+the quality of relationships between the class members' (p. 720). Dörnyei (2007) suggests that the first aspect conducive to a positive classroom environment is the cohesion that can be developed by the members of the group where learning is taking place. According to Dörnyei, cohesion is composed of two different phases: attraction and acceptance. Attraction is developed during first encounters where physical features, perceived competence and similarities in personality and attitudes can make students and teachers form a positive initial bond. Thus, the first impressions students get during initial course sessions are important. Teachers should regard the first session of a course as a sales challenge because they are presenting their product (teaching) to clients (learners). Teachers should not only be prepared to give students a concise and clear teaching plan that they are going to work with over the course, but also be prepared to give students some personal details to show 
who they are as people. First sessions should be used to start building a trustful and personalised relationship with students in order to make them feel related to teachers. There are diverse humanistic-affective activities that can be used for this non-academic purpose (see Moskowitz, 1978). Although Dörnyei (2007) considers that first impressions are not so important in the long run, I believe that they can be a first step to achieving a positive relationship with students.

Learning activities should be designed to encourage cooperation instead of competition among students (Dörnyei, 2001). The sense of frustration some students revealed in the studies reviewed when their peers made fun of them should be avoided. Students' mockery impacted negatively on other students' confidence and self-perception of competence, making them hesitant about their knowledge when doing a piece of homework and leading them to perceive communicating in English was a very difficult task they were not able to achieve. It is important, then, for teachers to make students aware that errors are a natural step in the complex task of learning a new language so students can see errors as their friends, not as their enemies. By teachers making students aware of the positive outcome of errors, in terms of identifying the areas they need to work on, learners can feel less apprehensive about making mistakes.

\subsection{Establishing good teacher-student relationships}

In educational settings the rapport a teacher establishes with students is one of the most important aspects in developing a motivating classroom environment. As Rogers (1962) states, 'it is the quality of the interpersonal encounter with the client which is the most significant element in determining effectiveness' ( $p .416)$. In the studies reviewed, students revealed that the teacher interpersonal skills are determinant in promoting a healthy teacher-student relationship. It is thus important to concentrate on building a trustful and empathic relationship with students in order to make them feel valued.

Current learner-centred education theory conceives of the teacher as a facilitator and not as an authoritarian figure in classrooms. Many teachers may not be aware that the relationships developed in language classrooms impact students not only for a term or course, but for longer. There are study reports that highlight the high value learners give to teachers who care, listen to them, understand their needs, respect them as individuals, and are open, honest and sensitive to their personal problems (Hascher, 2007; Lei, 2007; Bown and white, 2010). Students spend many hours of their lives in classrooms and positive human relationships in classrooms help them to develop positive self-concepts. In language classrooms, teachers are not only teaching English; they are also 
forming human beings who will be interacting with many people and impacting on them, thus the need to help students develop in an integral way is paramount.

\section{Conclusions}

The importance of this review lies in identifying foreign language learners' emotional experiences during instruction and showing how these experiences affected their motivation. The review indicates that there is a definite need for foreign language teachers to examine their teaching practices in order to address students' emotional experiences in classrooms as this may provide a challenge to practising teachers, who may think that it is not their job to cater to learners' affective needs as reflected in the criticisms humanistic methods faced during their introductory years (see Gadd, 1998). However, emotions have been revealed as strongly influential regarding foreign language learners' motivation not only during classroom instruction (Garret and Young, 2009; Imai, 2010; Méndez and Fabela, 2014) but also in individualised settings (Bown and White, 2010).

Language learning is a process replete with negative and positive emotions that can help our students not only to succeed in their language learning process but also to be more autonomous. Helping students to be more autonomous is a current concern in some contexts. In spite of great efforts that have been made to help language learners become more autonomous, a recent series of studies revealed that Mexican students rely greatly on teachers to be directed and motivated (Méndez, 2015). Thus, it is necessary to make explicit interventions in terms of the management of emotions in order to help language learners to be not only motivated but also more emotionally strategic (Oxford, 2015). As practising language teachers, we all want our students to be more emotionally intelligent so they can make the most of their language learning experience.

An important contribution of catering for language learners emotions is highlighted by Oxford (2015) in her current discussion about the psychological perspective of autonomous language learners; she demonstrates that emotional intelligence reduces stress and anxiety, decreases conflict, improves relationships and increases achievement. Oxford's discussion emphasises the importance of promoting appropriate management of language learners' emotions if we want them to be successful. Thus, it is necessary for language teachers to help their students make their emotions work for them and not against them.

Future research needs to be carried out in diverse contexts in order to find out what outcomes are derived from negative emotions and how specific contexts modify its impact. 
Future research also needs to make a comparison of the emotional experiences encountered by lower-level and proficient learners. Do students at different levels react differently to the same emotional experiences? Are the emotional experiences of proficient language learners different from those of lower-level learners? Do proficient language learners experience more positive than negative emotions? How is the motivation of proficient language learners affected by emotional experiences?

Future research on motivational factors that help students to overcome negative experiences should be done in different contexts in order to understand better how to help students maintain their levels of motivation in foreign language classes. In addition, the way students manage emotions should be investigated in order to design interventions to help students make their emotions work in favour of their learning processes as opposed to working against them.

\section{References}

Aragão, R. (2011). «Beliefs and emotions in foreign language learning». System, vol. 39: 302-313.

Arnold, J. (1999). Affect in language learning. Cambridge: Cambridge University Press.

Arnold, J., and Brown, D. H. (1999). «A map of the terrain». Inः J. Arnold (ed.). Affect in language learning (1-24). Cambridge: Cambridge University Press.

Barret, L. F; Mesquita, B.; Ochsner, K. N. and Gross, J. J. (2007). «The experience of emotion». Annual Review of Psychology, vol. 58: 373-403.

Benesch, S. (2012). Considering emotions in critical English language teaching. London: Routledge.

Blumenfeld, P. C. (1992). «Classroom learning and motivation: Clarifying and expanding goal theory». Journal of Educational Psychology, vol. 84: 272-281.

Bown, J., and White, C. J. (2010). «Affect in a self-regulatory framework for language learning». System, vol. 38: 432-443.

Carole, A. (1992) «Classrooms: Goals, structures and students motivation». Journal of Educational Psychology, vol. 84: 267-271.

Chang, L. Y.-H. (2010). «Group processes and EFL learners' motivation: A study of group dynamics in EFL classrooms». TESOL Quarterly, vol. 44: 129-133.

Deci, E. L., and Ryan, R. M. (1985). Intrinsic motivation and self-determination in buman behaviour. New York: Plenum. 
Dewaele, J-M. (2005). «Investigating the psychological and emotional dimensions in instructed language learning: Obstacles and possibilities». The Modern Language Journal, vol. 89: 367-380.

Dewaele, J. M. (2011). «Reflections on the emotional and psychological aspects of foreign language learning and use». Anglistik: International Journal of English Studies, vol. 22:23-42.

Dewaele, J. M. and Macintyre, P. D. (2014). «The two faces of Janus? Anxiety and enjoyment in the foreign language classroom». Studies in Second Language Learning and Teaching, vol. 4: 237-274.

Do, S. L., and Schallert, D. L. (2004), «Emotions and classroom talk: Toward a model of the role of affect in students' experiences of classroom discussions». Journal of Educational Psychology, vol. 96: 619-634.

Dörnyei, Z. (1994). «Motivation and motivating in the foreign language classroom». The Modern Language Journal, vol. 78: 273-284.

Dörnyei, Z.(2001). Motivational strategies in the language classroom. Cambridge: Cambridge University Press.

Dörnyei, Z* (2007). «Creating a motivating classroom environment». In: J. Cummins \& C. Davison (eds.). International handbook of English language teaching. New York: Springer: 719-731.

Efklides, A., and Volet, S. (2005). «Emotional experiences during learning* Multiple, situated and dynamic». Learning and Instruction, vol. 15:377-380.

Ekman, P. (2003). Emotions revealed: Understanding faces and feelings. London: Weidenfeld and Nicolson.

Ellis, R. (1994). The study of second language acquisition. Oxford: Oxford University Press.

GAdD, N. (1998). «Towards less humanistic English teaching». ELT Journal, vol. 52:223-234.

Gage, N., and Beliner, D. (1992). Educational psychology (5th ed.). Boston: Houghton Mifflin.

Gardner, R. (1985). Social psychology and second language learning: The role of attitudes and motivation. London: Edward Arnold.

Gardner, R. C., and Lambert, W. (1959). «Motivational variables in second language acquisition». Canadian Journal of Psychology, vol. 13: 266-272.

Gardner, R. C., and Lambert, W. E. (1972). Attitudes and motivation in second language learning. Rowley, Massachusetts: Newbury House Publishers.

Garret, P., and Young, R. F. (2009). «Theorizing affect in foreign language learning: An analysis of one learner's responses to a communicative Portuguese course». The Modern Language Journal, vol. 93: 209-226. 
Gläser-Zikuda, M. and Järvelä, S. (2008). «Application of qualitative and quantitative methods to enrich understanding of emotional and motivational aspects of learning». International Journal of Educational Research, vol. 47: 79-83.

Gläser-Zikuda, M*, and Fuß, S. (2008). «Impact of teacher competencies on student emotions: A multi-method approach». International Journal of Educational Research, vol. 47: 136-147.

Gläser-Zikuda, M.; Fuß, S.; Laukenmann, M.; Metz, K. and Randler, C. (2005). «Promoting students' emotion and achievement-instructional design and evaluation of the ECOLE-approach». Learning and Instruction, vol. 15: 481-495.

Graves, K. (2005). Designing language courses: A guide for teachers. Beijing, China: Foreign Language Teaching and Research Press.

Guilloteaux, M. J., and Dörnyei, Z. (2008). «Motivating language learners: A classroom-oriented investigation of the effects of motivational strategies on student motivation». TESOL Quarterly, vol. 42: 55-77.

HASCHER, T. (2007). «Exploring students' well-being by taking a variety of looks into the classroom». Hellenic Journal of Psychology, vol. 4: 331-349.

Hascher, T. (2008). «Quantitative and qualitative research approaches to assess student well-being». International Journal of Educational Research, vol. 47:84-96.

IMAI, Y. (2010). «Emotions in SLA: New insights from collaborative learning for an EFL Classroom». The Modern Language Journal, vol. 94: 278-292.

JACKson, J. (2002). «Reticence in second language case discussions: Anxiety and aspirations». System, vol. 30: 65-84.

Järvenova, H., and Järvelä, S. (2005). «How students describe the sources of their emotional and motivational experiences during the learning process: $A$ qualitative approach». Learning and Instruction, vol. 15: 465-480.

Kitano, K. (2001). «Anxiety in the college Japanese language classroom». The Modern Language Journal, vol. 85: 549-566.

Krashen, S. (1985). The input hypothesis: Issues and implications. London: Longman.

LEI, Q. (2007). «EFL teachers' factors and students affect». US-China Education Review, vol. 4:60-67.

Linnebrick-Garcia, L. and Pekrun, R. (2011). "Students' emotions and academic engagement: Introduction to the special issue». Contemporary Educational Psychology, vol. 36: 1-3.

Littrewood, W. (2000). «Do Asian students really want to listen and obey?». ELT Journal, vol. 54: 31-35. 
Macintyre, P. (2002). «Motivation, anxiety and emotion in second language acquisition». In: P. Robinson (ed.). Individual differences and instructed language learning. Amsterdam: John Benjamins Publishing: 45-68.

Macintyre, P. D.; Mackinnon, S. P., and Clément, R. (2009). «The baby, the bathwater, and the future of language learning motivation research». In: Z. Dörnyei and E. Ushioda (eds.). Motivation, language identity and the L2 self. Bristol, UK: Multilingual Matters: 43-65.

Macintyre, P. D.; Burns, C., and Jessome, A. (2011). «Ambivalence about communicating in a second language: A qualitative study of French immersion students' willingness to communicate». The Modern Language Journal, vol. 95: 81-96.

Méndez, M. G. (2011). «The motivational properties of emotions in foreign language learning». Colombian Applied Linguistics Journal, vol. 13: 43-59.

Méndez, M. G. and PeÑA, A. (2013). «Emotions as learning enhancers of foreign language learning motivation». PROFILE Journal, vol. 15: 109-124.

Méndez, M. G. and Fabela, M. (2014). «Emotions and their effects in a language learning Mexican context». System, vol. 42: 298-307.

Méndez, M. G.; Marin, A. and Hernandez, I. (2015). «Emotional experiences revealed by foreign language students at the UQROO». In: M. MÉNDEZ (ed.). Emotions reported by English language teaching major students in Mexico (147-169). Chetumal, Q. Roo: Universidad de Quintana Roo.

Méndez, M. G. (2015). Emotions reported by English language teaching major students in Mexico. Chetumal, Q. Roo: Universidad de Quintana Roo.

Mercer, S. (2005). «Using journals to investigate the learner's emotional experience of the language classroom». Estudios de Lingüistica Inglesa Aplicada, vol. 6: 63-91.

Mercer, S. (2011). «Language learner self-concept: Complexity, continuity and change». System, vol. 39: 335-346.

Meyer, D. K., and Turner, J. C. (2002). «Discovering emotion in classroom motivation research». Educational Psychologist, vol. 37:107-114.

Meyer, D. K., and Turner, J. C. (2006). «Re-conceptualizing emotion and motivation to learn in classroom contexts». Educational Psychology Review, vol. 18: 377-390.

Moskowitz, G. (1978). Caring and sharing in the foreign language classroom. Rowley, MA: Newbury House.

Oxford, R. L. (1995). «When emotion meets (meta) cognition in language learning histories». International Journal of Educational Research, vol. 23:581594. 
Oxford, R. L. (2015). «Expanded perspectives on autonomous learners». Innvovation in Language Learning and Teaching, vol. 9:58-71.

Pekrun, R. (2000). A social-cognitive, control-value theory of achievement emotions. Amsterdam: Elsevier Science B.V.

Pekrun, R.; Goetz, T.; Titz, W., and Perry, R. P. (2002). «Academic emotions in students' self-regulated learning and achievement: A program of qualitative and quantitative research». Educational Psychologist, vol. 37: 91-105.

Prinz, J. (2005). «Are emotions feelings?». Journal of Consciousness Studies, vol. 12:9-25.

Ryan, R. M., and Deci, E. L. (2000). "Self-determination theory and the facilitation of intrinsic motivation, social development, and well-being». American Psychologist, vol. 55: 68-78.

Rogers, C. (1962). "The interpersonal relationship: the core of guidance». Harvard Educational Review, vol. 32: 416-429.

Salonen, P.; Lehtinen, E., and Olminuora, E. (1998). «Expectations and beyond: The development of motivation and learning in a classroom context». Advances in Research on Teaching, vol. $7: 111-150$.

Sansone, C., and Thoman, D. B. (2005). «Does what we feel affect what we learn? Some answers and new questions». Language and Instruction, vol. 15: 507-515.

Scherer, K. R. (2005). «What are emotions? And how can they be measured?». Social Science Information, vol. 44: 695-729.

Schumann, J. H. (1998). The neurobiology of affect in language. Oxford: Blackwell. Shoaib, A., and Dörnyei, Z. (2004). «Affect in lifelong learningः Exploring L2 motivation as a dynamic process». In: P. Benson and D. NunAN (eds.), Learners' stories (23-41). Cambridge: Cambridge University Press.

Swain, M. (2013). «The inseparability of cognition and emotion». Language Teaching, vol. 46: 195-207.

TsE, L. (2000). «Student perceptions of foreign language studyः A qualitative analysis of foreign language autobiographies». The Modern Language Journal, vol. 84:69-84.

Turner, J. C.; Meyer, D. K. and Schweinle, A. (2003). «The importance of emotion in theories of motivation: empirical, methodological and theoretical considerations from a goal theory perspective». International Journal of Educational Research, vol. 39: 375-393.

Ushioda, E. (2003). «Motivation as a socially mediated process». In* D. LitTte, J. Ridley and E. Ushioda (eds.), Learner autonomy in the foreign language 
classroom: Learner, teacher, curriculum and assessment (90-102). Dublin, Ireland: Authentik.

Williams, M. and Burden, R. L. (1997). Psychology for language teachers: A social constructivist approach. Cambridge: Cambridge University Press.

Williams, M.; Burden, R.; Poulet, G. and Maun, L. (2004). «Learners' perceptions of their successes and failures in foreign language learning». Language Learning, vol. 30: 19-29.

Woodrow, L. (2006). «Anxiety and speaking English as a second language». RELC Journal, vol. 37: 308-328.

XIE, X. (2010). «Why are students quiet? Looking at the Chinese context and beyond». ELT Journal, vol. 64: 10-20.

YAN, J. X., and Horwitz, E. K. (2008). «Learners' perceptions of how anxiety interacts with personal and instructional factors to influence their achievement in English: A qualitative analysis of EFL learners in China». Language Learning, vol. 58: 151-183.

ZarrinabAdi, N. (2014), «Communicating in a second language: Investigating the effect of teacher on learners' willingness to communicate». System, vol.42: 288-295.

Zhang, X., and Head, K. (2010). «Dealing with learner reticence in the speaking class.» ELT Journal, vol. 64: 1-9. 